\title{
Effects of naloxone or transient weaning on secretion of LH and prolactin in lactating sows*
}

\author{
J. D. Armstrong, R. R. Kraeling† and J. H. Britt \\ Department of Animal Science, Physiology Program, North Carolina State University, Box 7621, \\ Raleigh, North Carolina 27695-762I, U.S.A.
}

\begin{abstract}
Summary. Sows $(\mathrm{N}=16)$ were infused intravenously for $8 \mathrm{~h}$ with saline or naloxone $(200 \mathrm{mg} / \mathrm{h})$ or their litters were transiently weaned for $8 \mathrm{~h}$. Before infusion, $200 \mathrm{mg}$ naloxone were administered to elevate quickly concentrations of naloxone. Blood samples were collected from sows at $15 \mathrm{~min}$ intervals for $24 \mathrm{~h}$, beginning $8 \mathrm{~h}$ before and continuing until $8 \mathrm{~h}$ after imposition of treatments during the middle 8 -h segment. Frequency of episodic release of $\mathrm{LH}$ and concentrations of prolactin were similar before, during and after infusion of saline. Average concentration of $\mathrm{LH}$ was greater during the last than during the middle 8-h segment when sows were given saline. Frequency of episodic release of LH increased and concentrations of prolactin decreased during infusion of naloxone or transient weaning; however, average concentration of $\mathrm{LH}$ increased during transient weaning, but not during infusion of naloxone. After transient weaning or infusion of naloxone, frequency of release of LH decreased, returning to pretreatment values in sows infused with naloxone but remaining above pretreatment values in sows subjected to transient weaning. At the resumption of suckling by litters in sows subjected to transient weaning, prolactin increased to levels not different from those observed during the 8-h pretreatment segment. Prolactin did not increase until $4-5 \mathrm{~h}$ after cessation of naloxone infusion. We conclude that continuous infusion of naloxone altered secretory patterns of LH and prolactin. Collectively these results provide evidence that the immediate effects of weaning on LH and prolactin in sows are mediated in part through a mechanism involving endogenous opioid peptides.
\end{abstract}

Keywords: LH; endogenous opioid peptides; naloxone; lactation; prolactin

\section{Introduction}

Lactation in the sow is normally characterized by an absence of preovulatory-sized follicles, low blood concentrations of gonadotrophins and hyperprolactinaemia (reviewed by Britt et al., 1985). Hourly administration of gonadotrophin-releasing hormone (GnRH) stimulates follicular growth, oestrus and ovulation in lactating sows (Cox \& Britt, 1982a). Weaning results in increased GnRH in the hypothalamus, increased LH in the anterior pituitary (Cox \& Britt, 1982b), an increase in frequency of episodic release of $\mathrm{LH}$ and a decrease in prolactin (Shaw \& Foxcroft, 1985; Cox \& Britt, 1986). Suckling therefore limits follicular growth by reducing secretion of GnRH by the hypothalamus.

Studies utilizing opiate agonists and antagonists have demonstrated that endogenous opioid peptides inhibit LH and stimulate prolactin (Meites et al., 1979; Grossman \& Rees, 1983; Bicknell,

\footnotetext{
${ }^{*}$ Reprint requests to Dr J. H. Britt.

†Present address: USDA, ARS, Athens, GA 30613, U.S.A.
} 
1985; Malven, 1986). Administration of naloxone, an opioid antagonist, during lactation resulted in increased LH in rats (Sirinathsinghji \& Martini, 1984), ewes (Gregg et al., 1986), cows (Whisnant et al., 1986), women (Ishizuka et al., 1984) and sows (Barb et al., 1986; Mattioli et al., 1986) and suppressed serum prolactin in rats (Ferland et al., 1978; Miki et al., 1981; Sirinathsinghji \& Martini, 1984), ewes (Gregg et al., 1986) and sows (Mattioli et al., 1986).

The objective of the present study was to test the hypothesis that endogenous opioid peptides mediate the effects of suckling on $\mathrm{LH}$ and prolactin in the sow. In preliminary studies, Armstrong et al. (1986b) were unable to establish that a single injection of naloxone $(0 \cdot 5-2 \mathrm{mg} / \mathrm{kg})$ would consistently stimulate secretion of $\mathrm{LH}$ in lactating sows, even though each dose caused a significant suppression of serum prolactin concentration. In this study, therefore, we compared the effects of continuous antagonism of opioid receptors by infusion of naloxone for $8 \mathrm{~h}$ with those of physical removal of the suckling stimulus (transient weaning of litter) for $8 \mathrm{~h}$ on secretion of LH and prolactin.

\section{Materials and Methods}

Animals and treatments. Multiparous crossbred sows $(\mathrm{N}=16,187 \pm 7 \mathrm{~kg}$, mean \pm s.e.m. $)$ that farrowed during April or July 1985 were used. Litter sizes were standarized within $48 \mathrm{~h}$ after parturition and sows and piglets were penned in individual farrowing crates throughout lactation. Sows were fed to appetite twice daily $(07: 00 \mathrm{and} 16: 00 \mathrm{~h}) \mathrm{a}$ corn-soybean meal diet supplemented with vitamins and minerals according to NRC (1979) guidelines.

Lactating sows were used in two replicates to evaluate whether continuous blockade of opioid receptors by infusion of naloxone would cause changes in secretion of $\mathrm{LH}$ and prolactin similar to those which occur during physical removal of the suckling stimulus (transient weaning). In Replicate 1 (April 1985), sows were randomly assigned to one of the following treatments: (1) infusion of saline $(\mathrm{N}=4),(2)$ infusion of naloxone $(200 \mathrm{mg} / \mathrm{h}, \mathrm{N}=4)$, or (3) transient weaning of litters $(\mathrm{N}=4)$. In Replicate 2 (July 1985), transient weaning alone was re-evaluated to corroborate its effect on frequency of release of $\mathrm{LH}$. In both replicates, the designated treatment was imposed during the middle 8-h segment of a 24-h sampling interval.

Vena cava catheters were inserted (Armstrong et al., 1986a) at least $24 \mathrm{~h}$ before the start of blood sampling. Sows were fitted with single (transient weaning) or dual (control and naloxone) catheters, and blood samples were collected at 15-min intervals for $24 \mathrm{~h}$ (06:00 to 06:00 h) encompassing the three 8-h segments before, during and after infusion or transient weaning. Samples were stored at $4^{\circ} \mathrm{C}$ for $18 \mathrm{~h}$, centrifuged at $3000 \mathrm{~g}$ for $30 \mathrm{~min}$ and serum was decanted and stored at $-20^{\circ} \mathrm{C}$ until assayed.

Transient weaning was accomplished by removing litters from farrowing crates and isolating them from sows for $8 \mathrm{~h}$. Saline or naloxone $(200 \mathrm{mg} / \mathrm{h}$ or $1 \cdot 1 \mathrm{mg} / \mathrm{kg} / \mathrm{h})$ was infused (i.v.) at the rate of $24 \mathrm{ml} / \mathrm{h}$ through two identically calibrated Harvard (South Natick, MA) infusion pumps. Naloxone (E. I. DuPont de Nemours \& Co., Wilmington, DE) was administered in solution with $0.87 \%(\mathrm{w} / \mathrm{v})$ sodium chloride. Before infusion, $200 \mathrm{mg}$ naloxone were administered (i.v.) to elevate concentrations of the opioid antagonist quickly. Control sows were treated with $10 \mathrm{ml}$ saline before continuous infusion of saline.

Hormone assays. Luteinizing hormone was measured by validated radioimmunoassay procedures (Stevenson et al., 1981) except that the antiserum (GDN No. 566) was used at an initial dilution of 1:90000 and the period of incubation with antiserum was increased from 24 to $48 \mathrm{~h}$. These changes reduced the mean assay sensitivity from 0.4 to $0.2 \mathrm{ng} / \mathrm{ml}$. All samples collected were analysed for $\mathrm{LH}$ and intra- and inter-assay coefficients of variation (CVs) for 4 assays were 9.0 and $10.6 \%$, respectively. Prolactin concentrations were determined as previously described (Kraeling $e t$ al., 1982). Every fourth sample collected was analysed for prolactin and the intra-assay CV was $9 \cdot 0 \%$.

Statistical analyses. Data for serum concentrations of $\mathrm{LH}$ and prolactin were analysed by split-plot analyses of variance (Gill \& Hafs, 1971) using general linear models procedures (SAS, 1982). The 24-h sampling interval was divided into three 8 -h segments representing the sampling times before, during and after treatment. Data were analysed first using a model with treatment, sow, segment and sample as discrete (class) variables. Treatment and segment and the segment $\times$ treatment interaction were tested with sow within treatment and segment $\times$ sow within treatment as the error terms, respectively. A split-plot analysis was then performed within treatment or within segment to define more clearly the effects of segment or treatment on prolactin or LH secretion. Error terms used to test treatment and segment in these two analyses were sow within treatment and the sow $\times$ segment interaction, respectively. In all analyses, comparisons among means were made by Duncan's multiple range test (Steele \& Torrie 1980) using the appropriate error mean square.

An episodic release of LH (LH peak) was defined by the method of Goodman \& Karsch (1980). Basal LH was the mean of all samples during an 8-h segment excluding those associated with peaks. Amplitude of an $\mathrm{LH}$ peak was the difference between the maximal concentration during a peak and basal LH for that specific 8-h segment. Frequency and amplitude of LH peaks were analysed using a model with treatment, sow and segment as the independent variables as described for prolactin and LH concentrations. 

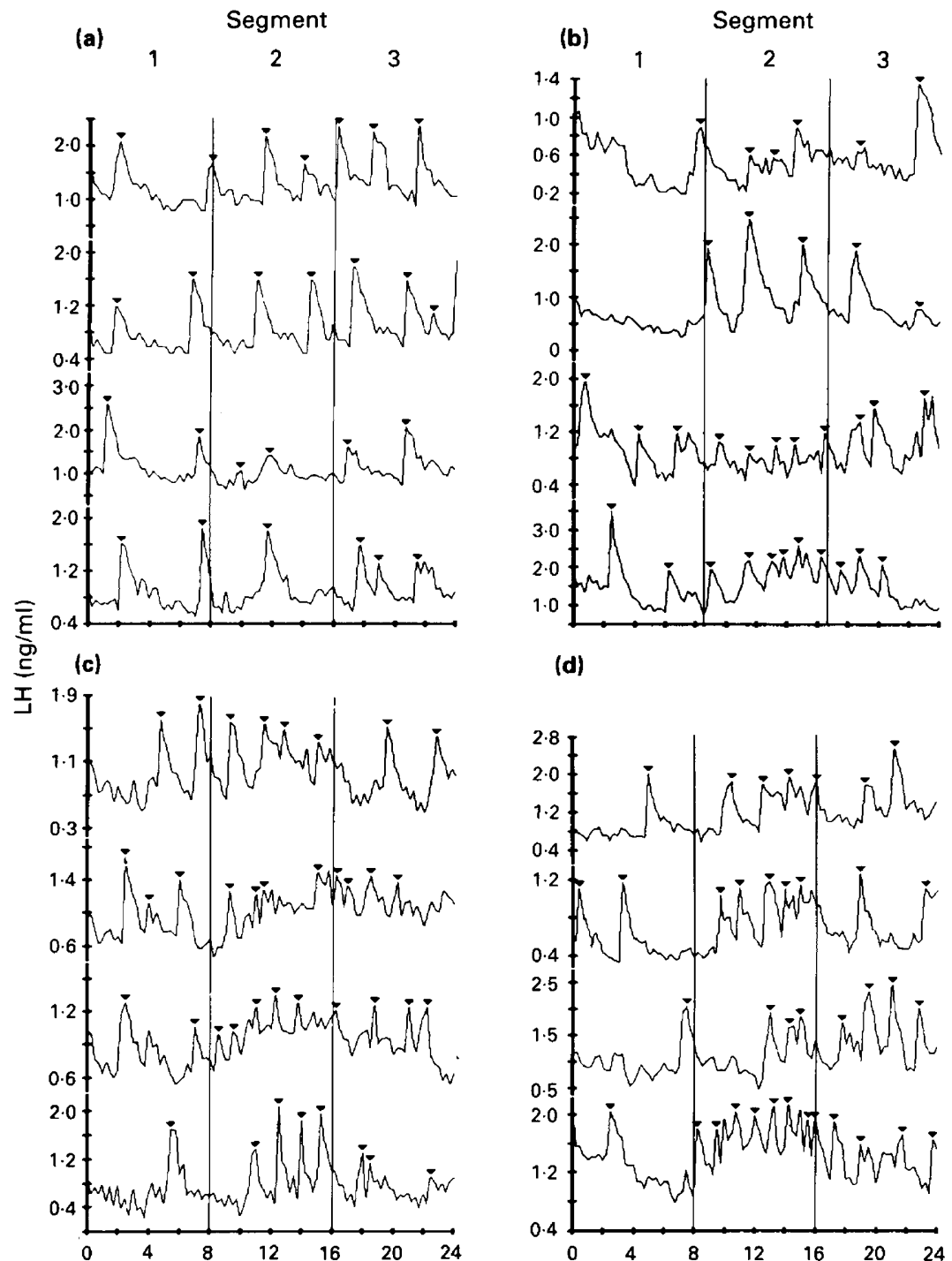

(d)

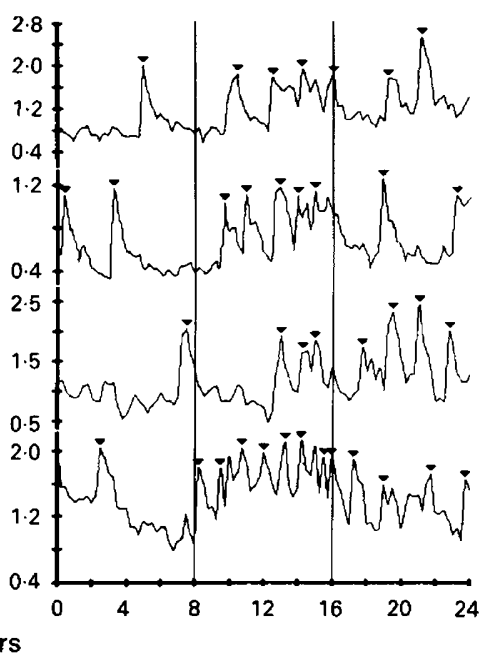

Fig. 1. Profiles of secretion of $\mathrm{LH}$ for individual sows before, during and after infusion of saline (a), infusion of naloxone (b), or transient weaning (c, Replicate 1; d, Replicate 2). Samples were obtained at 15 -min intervals from 0 through $24 \mathrm{~h}$. Infusion of saline or naloxone, or transient weaning occurred during the second 8 -h segment. Note that values of $\mathrm{LH}$ on the $y$ axis vary among individual sows. Triangles indicate an episodic release of $\mathrm{LH}$.

\section{Results}

Characteristics of secretion of $\mathrm{LH}$ and average concentrations of prolactin are given in Table 1 . Individual profiles of secretion of $\mathrm{LH}$ are in Fig. 1 and average concentrations of prolactin are in Fig. 2.

Neither frequency or amplitude of release of LH (Table 1; Fig. 1a) nor average concentration of prolactin (Fig. 2) was affected by infusion of saline. The average concentration of LH in sows 


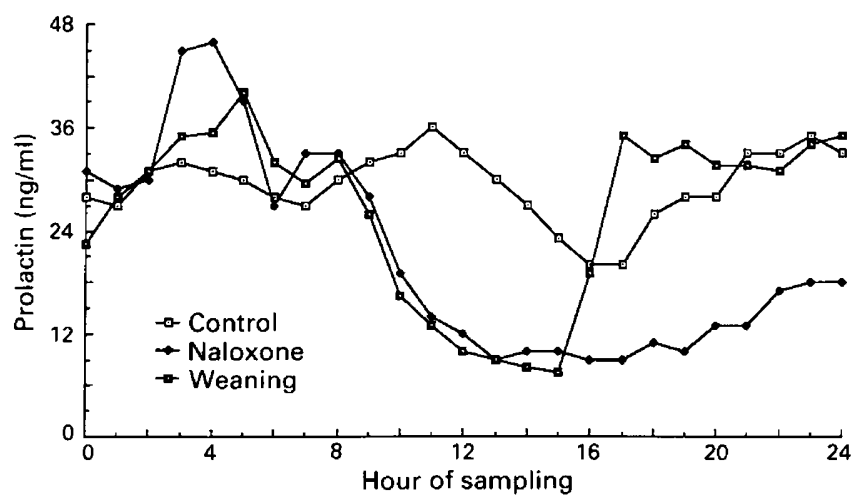

Fig. 2. Concentrations of prolactin before $(0-8 \mathrm{~h})$, during $(8-16 \mathrm{~h})$ and after $(16-24 \mathrm{~h})$ infusion of saline or naloxone or transient weaning (weaning). Standard errors $(\mathrm{ng} / \mathrm{ml}$ ) ranged from 1 to 7,1 to 18 and 1 to 10 for control, naloxone-treated and transiently weaned sows, respectively.

Table 1. Average concentration of prolactin and characteristics of release of LH in lactating sows for 8-h segments before (Segment 1), during (Segment 2) and after (Segment 3) infusion of saline or naloxone $(1 \cdot 1 \mathrm{mg} / \mathrm{kg} / \mathrm{h})$, or transient weaning of the litter

\begin{tabular}{|c|c|c|c|c|}
\hline Treatment & Measure & Segment 1 & Segment 2 & Segment 3 \\
\hline \multirow[t]{2}{*}{ Saline } & $\begin{array}{l}\mathrm{LH} \mathrm{ng} / \mathrm{ml} \\
\text { Peaks } / 8 \mathrm{~h} \\
\text { Amplitude }\end{array}$ & $\begin{array}{l}1 \cdot 02 \pm 0 \cdot 3^{\mathrm{a}, \mathrm{b}} \\
2 \cdot 00 \pm 0 \cdot 00 \\
0 \cdot 98 \pm 0 \cdot 10\end{array}$ & $\begin{array}{l}0.99 \pm 0.03^{\mathrm{a}} \\
1.8 \pm 0.3 \\
0.85 \pm 0.14\end{array}$ & $\begin{array}{l}1 \cdot 17 \pm 0.04^{b} \\
2.5 \pm 0.3 \\
0.82 \pm 0.14\end{array}$ \\
\hline & $\begin{array}{l}\text { Prolactin } \\
\mathrm{ng} / \mathrm{ml}\end{array}$ & $29 \pm 1$ & $29 \pm 2$ & $29 \pm 11$ \\
\hline \multirow[t]{2}{*}{ Naloxone } & $\begin{array}{l}\text { LH ng/ml } \\
\text { Peaks } / 8 \mathrm{~h} \\
\text { Amplitude }\end{array}$ & $\begin{array}{l}0.88 \pm 0.04 \\
1.5 \pm 0.6^{\mathrm{a}} \\
0.65 \pm 0.31\end{array}$ & $\begin{array}{l}1.03 \pm 0.03 \\
4.3 \pm 0.8^{\mathrm{b}} \\
0.66 \pm 0.25\end{array}$ & $\begin{array}{l}0.92 \pm 0.02 \\
2.5 \pm 0.3 \\
0.82 \pm 0.05\end{array}$ \\
\hline & $\begin{array}{l}\text { Prolactin } \\
\mathrm{ng} / \mathrm{ml}\end{array}$ & $35 \pm 4^{\mathrm{a}}$ & $14 \pm 2^{b}$ & $\pm 2^{b}$ \\
\hline \multirow[t]{2}{*}{$\begin{array}{l}\text { Transient } \\
\text { weaning }\end{array}$} & $\begin{array}{l}\mathrm{LH} \text { ng/ml } \\
\text { Peaks } / 8 \mathrm{~h} \\
\text { Amplitude }\end{array}$ & $\begin{array}{l}0.93 \pm 0.04^{\mathrm{a}} \\
1.8 \pm 0.3^{\mathrm{a}} \\
0.95 \pm 0.14\end{array}$ & $\begin{array}{l}1 \cdot 12 \pm 0.03^{\mathrm{b}} \\
4.5 \pm 0.4^{\mathrm{b}} \\
0.65 \pm 0.20\end{array}$ & $\begin{array}{l}1 \cdot 06 \pm 0.03^{a \cdot b} \\
3 \cdot 1 \pm 0.4^{c} \\
0.76 \pm 0.11\end{array}$ \\
\hline & $\begin{array}{l}\text { Prolactin } \\
\mathrm{ng} / \mathrm{ml}\end{array}$ & $\pm 3^{\mathrm{a}}$ & $\pm 2^{\mathrm{b}}$ & $\pm 2^{\mathrm{a}}$ \\
\hline
\end{tabular}

Values are mean \pm s.e.m.

Means in same row with different superscripts are different $(P<0.05)$.

infused with saline was greater $(P<0.05)$ during the third than during the second 8 -h segment (Table 1).

Infusion of naloxone resulted in an increase in frequency of release of $\mathrm{LH}(P<0.05$; Table 1 ; Fig. 1b) and a decline in prolactin $(P<0.05$; Fig. 2$)$. There was variation $(P<0.05)$ among 
naloxone-infused sows in absolute frequency of LH release (Fig. 1b). Average concentration of LH and amplitude of $\mathrm{LH}$ release were not affected by naloxone $(P>0 \cdot 10$; Table 1$)$.

Frequency of $\mathrm{LH}$ release during the 8-h segment after the end of the naloxone infusion was similar $(P>0 \cdot 10)$ to the frequency during the 8-h pre-infusion segment (Table 1; Fig. 1b). Concentration of prolactin remained suppressed for $4-5 \mathrm{~h}$ after cessation of naloxone infusion (Fig. 2). Concentration of prolactin during the last 8 - $h$ segment in naloxone-infused sows was lower $(P<0.05)$ than concentrations during the pre-infusion segment and lower than concentrations observed during the last 8-h sampling segment in sows of the two other treatment groups (Table 1).

Changes in patterns of secretion of $\mathrm{LH}$ in individual sows in response to transient weaning are depicted in Fig. 1(c) (Replicate 1) and Fig. 1(d) (Replicate 2). Concentrations of prolactin and characteristics of $\mathrm{LH}$ release in sows subjected to transient weaning were similar between Replicates I and 2; therefore, values were averaged and are depicted in Table 1 and Fig. 2. Average concentration and frequency of episodic release of $\mathrm{LH}$ increased $(P<0.05)$ during transient weaning, but amplitude of release of $\mathrm{LH}$ was similar before, during and after transient weaning (Table 1; Figs Ic \& d). Frequency of episodic release of LH declined $(P<0.05)$ after replacement of litters; however, it was still greater during the last 8-h segment than during the initial 8-h segment (Table 1). Average prolactin concentration decreased during transient weaning $(P<0.01$, Table 1$)$ and increased after replacement of litters (Fig. 2). Concentrations of prolactin during the last 8-h segment were similar between saline-treated sows and those subjected to transient weaning (Table 1; Fig. 2).

\section{Discussion}

In this experiment, transient weaning or chemical antagonism of opioid receptors with naloxone caused similar increases in frequency of episodic release of $\mathrm{LH}$. The effects of naloxone reported herein are in agreement with results from other studies in which naloxone stimulated release of LH in lactating rats (Sirinathsinghji \& Martini, 1984), cows (Whisnant et al., 1986), ewes (Gregg et al., 1986) and sows (Barb et al., 1986; Mattioli et al., 1986).

Transient weaning for $8 \mathrm{~h}$ resulted in increased serum $\mathrm{LH}$ values (Fig. 1; Table 1), which is consistent with results from other experiments (Shaw \& Foxcroft, 1985; Cox \& Britt, 1986) in which samples were collected frequently for several hours. For example, Shaw \& Foxcroft (1985) obtained samples at 15-min intervals from $12 \mathrm{~h}$ before until $48 \mathrm{~h}$ after weaning and demonstrated that frequency of release and concentration of $\mathrm{LH}$ increased after weaning.

Evidence from several studies indicates that the effect of suckling in the pig is mediated through the hypothalamus. Weaning results in an increase in GnRH in the hypothalamus and $\mathrm{LH}$ in the anterior pituitary (Cox \& Britt, 1982a). Suckling does not block the anterior pituitary's ability to release LH in response to GnRH (Bevers et al., 1981) and hourly pulses of GnRH in lactating sows results in follicular growth and ovulation (Cox \& Britt, 1982a). Most evidence also indicates that the effects of opioids on LH are mediated through the hypothalamus and GnRH secretion (Drouva et al., 1981; Ferin et al., 1982; Rasmussen et al., 1983; Wiesner et al., 1984) rather than through effects exerted at the pituitary gonadotrophe. For example, suckling suppressed GnRH levels in the medial basal hypothalamus and stalk median eminence (Cox \& Britt, 1982a) in pigs and stimulated release of $\beta$-endorphin into hypophysial portal blood in ewes (Gordon et al., 1987). However, two reports demonstrated that antagonists or agonists of opioid peptides could alter $\mathrm{LH}$ release from pituitary cells in vitro (Chao et al., 1986; Blank et al., 1986). While it is possible that opioids might have exerted direct effects on pituitary secretion of LH in the current study, this seems unlikely since Armstrong et al. (1986b) previously found that exogenous GnRH alone or GnRH plus naloxone caused the release of similar amounts of LH in lactating sows. Suckling and opioids therefore apparently modify LH in the pig through the hypothalamus. Although we did not measure changes in brain opioids in response to transient weaning, results reported herein are consistent with the concept that transient weaning alters opioid activity in the hypothalamus. In support of this 
concept, we observed that administration of the opioid agonist, morphine, blocked the stimulatory effects of transient weaning on LH (Armstrong et al., 1986c).

Results from these experiments also provide indirect evidence that suckling affects prolactin secretion in sows through a mechanism that involves opioids. Both transient weaning and infusion of naloxone resulted in similar declines in serum prolactin values. Others reported that weaning of the litter (Stevenson et al., 1981; Shaw \& Foxcroft, 1985) or administration of naloxone (Mattioli et al., 1986) resulted in a decline in prolactin in the sow. Agonists of opioids typically elevate prolactin values (Bruni et al., 1977; Meites et al., 1979; Shaar \& Clemens, 1980; Selmanoff \& Gregerson, 1986) and suckling caused an increase in serum prolactin and $\beta$-endorphin concentrations in rats (Riskind et al., 1984) and sheep (Gordon et al., 1987).

The observation that prolactin increased slowly (Fig. 2) after cessation of naloxone infusion may be partly explained by the half-life of naloxone ( $30-40 \mathrm{~min}$; Ngai et al., 1976). Concentrations of prolactin began increasing in all naloxone-infused sows about $4-5 \mathrm{~h}$ after infusions were stopped. A single, small dose of naloxone $(0.5 \mathrm{mg} / \mathrm{kg})$ is sufficient to suppress serum prolactin values for about $60 \mathrm{~min}$ in lactating sows (Armstrong et al., 1986b); therefore, the 4-5 h delay before prolactin began to increase in naloxone-infused sows in the present study may be related to the higher dose and to the difference in pharmacokinetics associated with constant infusion rather than a single intravenous injection. Alternative explanations for the slow increase in prolactin after cessation of naloxone infusion could be the development of acute tolerance or differences in sucking patterns by the litter. Owens \& Cicero (1981) demonstrated that pretreatment with naloxone reduced naloxone-induced increases in serum $\mathrm{LH}$ in male rats. Naloxone administered to male sheep at 4-h intervals was associated with an incremental decline in the increase in $\mathrm{LH}$ after each injection of naloxone (Ebling \& Lincoln, 1985). Differences in prolactin observed during the 8-h segment following cessation of naloxone or transient weaning may have been related to differences in the suckling activity of the litter. Although occurrence of suckling bouts was not recorded, litters in the transient weaning group initiated immediate vigorous sucking when returned to their dam, in contrast to the regular periods of sucking by litters in sows infused with naloxone.

Our results indicate that other factors may also contribute to the effects of suckling on $\mathrm{LH}$ and prolactin. Although both transient weaning and naloxone caused a significant increase in frequency of episodic release of $\mathrm{LH}$, only transient weaning caused an increase in average concentration of LH (Table 1). Differences in LH and prolactin values between naloxone-infused and transientlyweaned sows were also observed during the 8-h segment after treatment. Frequency of episodic release of LH returned to pre-treatment levels after cessation of naloxone: however, frequency remained greater than pre-treatment values following cessation of transient weaning. Prolactin remained suppressed following cessation of naloxone, but returned to pre-treatment levels after cessation of transient weaning (Table 1). As discussed previously, the difference in response of prolactin to treatments may have been in part due to the half-life of naloxone or occurrence of suckling bouts; however, the same explanations cannot be true for the disparity in LH secretion observed after cessation of treatments. For example, if the effects of suckling were mediated exclusively by opioids, one would expect the stimulatory effects of naloxone on LH to persist after cessation of infusion (as was observed for the inhibitory effects toward prolactin). The opposite was observed; frequency of LH release was greater after cessation of transient weaning than after cessation of naloxone. This response would be consistent with the development of acute tolerance (Owens \& Cicero, 1981; Ebling \& Lincoln, 1985) or factors in addition to opioids may mediate some of the effects of suckling on LH.

Paper No. 10546 of the Journal Series of the North Carolina Agricultural Research Service, Raleigh, NC 27695-7621. The use of trade names in this publication does not imply endorsement by the North Carolina Agricultural Research Service of the products named, or criticism of similar ones not mentioned. Research was funded in part by Competitive Grant 85-CRCR-1-1849 from the United States Department of Agriculture. 
We thank T. Steffel and D. Gladden for care of animals; V. Hedgpeth and L. Price-Taras for excellent assistance with the assays; S. Mizelle and M. Galloway for typing the manuscript; $\mathrm{Dr}$ L. E. Reichert for pig LH (LER 786-3) and prolactin (LER 2073); Dr G. D. Niswender for antiserum to pig LH (GND No. 566).

\section{References}

Armstrong, J.D., Britt, J.H. \& Cox, N.M. (1986a) Seasonal differences in function of the hypothalamichypophysial-ovarian axis in weaned primiparous sows. J. Reprod. Fert. 78, 11-20.

Armstrong, J.D., Kraeling, R.R. \& Britt, J.H. (1986b) Effect of bolus administration of naloxone on secretion of LH and prolactin in lactating sows. J. Anim. Sci. 63, (Suppl. 1), 332, Abstr.

Armstrong, J.D., Kraeling, R.R. \& Britt, J.H. (1986c) Endogenous opioid peptides mediate the effects of suckling on LH during lactation in sows. J. Anim. Sci. 63 (Suppl. 1), 57, Abstr.

Barb, C.R., Kraeling, R.R., Rampacek, G.B. \& Whisnant, C.S. (1986) Opioid inhibition of luteinizing hormone secretion in the postpartum lactating sow. Biol. Reprod. 35, 368-371.

Bevers, M.M., Willemse, A.H., Kruip, Th.A.M. \& van de Wiel, D.F.M. (1981) Prolactin levels and the LH response to synthetic GnRH in the lactating sow. Anim. Reprod. Sci. 4, 155-163.

Bicknell, R.J. (1985) Endogenous opioid peptides and hypothalamic neuroendocrine neurones. $J$. Endocr. $107,473-446$.

Blank, M.S., Fabbri, A., Catt, K.J. \& DuFau, M.L. (1986) Inhibition of luteinizing hormone release by morphine and endogenous opiates in cultured pituitary cells. Endocrinology 118, 2097-2101.

Britt, J.H., Armstrong, J.D., Cox, N.M. \& Esbenshade, K.L. (1985) Control of follicular development during and after lactation in sows. J. Reprod. Fert., Suppl. 33, 37-54.

Bruni, J.F., Van Vugt, D.A., Marshall, S. \& Meites, J. (1977) Effects of naloxone, morphine and methionine enkephalin on serum prolactin, luteinizing hormone, follicle stimulating hormone, thyroid stimulating hormone, thyroid stimulating hormone and growth hormone. Life Sci. 21, 461-466.

Chao, C.C., Malven, P.V. \& Moss, G.E. (1986) Direct opioid regulation of pituitary release of bovine luteinizing hormone. Life Sci. 39, 527-534.

Cox, N.M. \& Britt, J.H. (1982a) Pulsatile administration of GnRH to lactating sows: Endocrine changes associated with induction of fertile estrus. Biol. Reprod. 27, 1126-1137.

Cox, N.M. \& Britt, J.H. (1982b) Relationships between endogenous $\mathrm{GnRH}$, gonadotropins and follicular development after weaning in sows. Biol. Reprod. 27, $70-78$.

Cox, N.M. \& Britt, J.H. (1986) Pulsatile secretion of luteinizing hormone and follicle stimulating hormone and their relationship to secretion of estradiol and the onset of estrus in weaned sows. Anim. Reprod. Sci. $12,201-211$.
Drouva, S.A., Epelbaum, J., Tapia-Arancibia, L., Laplante, E. \& Kordon, C. (1981) Opiate receptors modulate LHRH and SRIF release from mediobasal hypothalamus. Neuroendocrinology 32, 163-167.

Ebling, F.J.P. \& Lincoln, G.A. (1985) Endogenous opioids and the control of seasonal LH secretion in Soay rams. J. Endocr. 107, 341-353.

Ferin, M., Wehrenberg, W.B., Lam, N.Y., Alston, E.J. \& van de Wiele, R.L. (1982) Effects and site of action of morphine on gonadotropin secretion in the female rhesus monkey. Endocrinology 111, 1652-1656.

Ferland, L., Kledik, G.S., Cusan, L. \& Labrie, F. (1978) Evidence for a role of endorphins in stress- and suckling-induced release in the rat. Molec. cell. Endocr. 12, 267-272.

Gill, J.L. \& Hafs, H.D. (1971) Analysis of repeated measurements of animals. J. Anim. Sci. 33, 331-336.

Goodman, R.L. \& Karsch, F.J. (1980) Pulsatile secretion of luteinizing hormone: differential suppression by ovarian steroids. Endocrinology 107, 1286-1290.

Gordon, K., Renfree, M.B., Short, R.V. \& Clark, I.J. (1987) Hypothalamo-pituitary portal blood concentrations of $\beta$-endorphin during suckling in the ewe. $J$. Reprod. Fert. 79, 397-408.

Gregg, D.W., Moss, G.E., Hudgens, R.E. \& Malven, P.V. (1986) Endogenous opioid modulation of luteinizing hormone and prolactin secretion in postpartum ewes and cows. J. Anim. Sci. 63, 838-847.

Grossman, A. \& Rees, L.H. (1983) The neuroendocrinology of opioid peptides. Br. med. Bull. 39, 83-88.

Ishizuka, B., Quigley, M.E. \& Yen, S.S.C. (1984) Postpartum hypogonadotropinism: Evidence for increased opioid inhibition. Clin. Endocr. 20,573-578.

Kraeling, R.R., Rampacek, G.B., Cox, N.M. \& Kiser, T.E. (1982) Prolactin and luteinizing hormone secretion after bromocryptine (CB-154) treatment in lactating sows and ovariectomized gilts. J. Anim. Sci. 54, 1212-1220.

Malven, P.V. (1986) Inhibition of pituitary LH release resulting from endogenous opioid peptides. Dom. Anim. Endocr. 3, 135-144.

Mattioli, M., Conte, F., Seren, E. \& Galeati, G. (1986) Effect of naloxone on plasma concentrations of prolactin and LH in lactating sows. J. Reprod. Fert. 76, 167-173.

Meites, J., Bruni, J.F., Van Vugt, D.A., Smith, A.F. \& Fioretti, P. (1979) Relation of endogenous opioid peptides and morphine to neuroendocrine functions. Life Sci. 24, 1325-1336.

Miki, N., Sonntag, W.E., Forman, L.J. \& Meites, J. (1981) Suppression by naloxone of rise in plasma growth hormone and prolactin induced by suckling. Proc. Soc. exp. Biol. Med. 168, 461-466. 
Ngai, S.H., Berkowitz, B.A., Yang, J.C., Hempstead, J. \& Spector, S. (1976) Pharmacokinetics of naloxone in rats and man: basis for its potency and short duration of action. Anesthesiology 44, 398-401.

NRC (1979) Nutrient requirements of pigs, 8th edn. National Academy of Science, Washington, D.C.

Owens, D.P. \& Cicero, T.J. (1981) Development of acute tolerance to the effects of naloxone on the hypothalamic-pituitary-luteinizing hormone axis in the male rat. J. Pharmacol. exp. Ther. 216, 135-141.

Rasmussen, D.D., Liu, J.H., Wolf, P.L. \& Yen, S.S.C. (1983) Endogenous opioid regulation of gonadotropin-releasing hormone release from the human fetal hypothalamus in vitro. J. clin. Endocr. Metab. 57, 881-884.

Riskind, P.N., Millard, W.J. \& Martin, J.B. (1984) Opiate modulation of the anterior pituitary hormone response during suckling in the rat. Endocrinology 114, 1232-1237.

SAS (1982) SAS User's Guide: Statistics. Statistical Analysis System Inc., Cary.

Selmanoff, M. \& Gregerson, K.A. (1986) Sucklinginduced prolactin release is suppressed by naloxone and stimulated by beta-endorphin. Neuroendocrinology 42, 255-259.

Shaar, C.J. \& Clemens, J.A. (1980) The effects of opiate agonists on growth hormone and prolactin release in rats. Fedn Proc. Fedn Am. Socs exp. Biol. 39, 2539-2543.
Shaw, H.J. \& Foxcroft, G.R. (1985) Relationship between $\mathrm{LH}, \mathrm{FSH}$, and prolactin secretion and reproductive activity in the weaned sow. J. Reprod. Fert. $75,17-28$.

Sirinathsinghji, D.J.S. \& Martini, L. (1984) Effects of bromocryptine and naloxone on plasma levels of prolactin, LH and FSH during suckling in the female rat Responses to gonadotrophin releasing hormone. $J$. Endocr. 100, 175-182.

Steel, R.G.D. \& Torrie, J.H. (1980) Principles and Procedures of Statistics: A Biomedical Approach. McGraw-Hill Book Company, New York.

Stevenson, J.S., Cox, N.M. \& Britt, J.H. (1981) Role of the ovary in controlling luteinizing hormone, follicle stimulating homrone, and prolactin secretion during and after lactation in pigs. Biol. Reprod. 24, 341-353.

Whisnant, C.S., Kiser, T.E., Thompson, F.N. \& Barb, C.R. (1986) Naloxone infusion increases pulsatile luteinizing release in postpartum beef cows. Dom. Anim. Endocr. 3, 49-54.

Wiesner, J.B., Koenig, J.I., Krulich, L. \& Moss, R.L. (1984) Site of action for beta-endorphin-induced changes in plasma luteinizing hormone and prolactin in the ovariectomized rat. Life Sci. 34, 1463-1473.

Received 8 September 1987 